\title{
Hydrothermal fluid circulations in the western Pyrenees: new data on stable isotopes, in-situ gas analysis and fluid inclusions
}

\author{
Guillaume Barré ${ }^{1,2, *}$, Alexy Elias-Bahnan ${ }^{3}$, Geoffrey Motte $^{1}$, Maxime Ducoux ${ }^{1,2}$, Guilhem \\ Hoareau $^{1}$, Dimitri Laurent ${ }^{3}$, and Eric C. Gaucher ${ }^{2}$ \\ ${ }^{1}$ CNRS/TOTAL/Univ. Pau \& Pays Adour/ E2S UPPA, Laboratoire des Fluides Complexes et leurs \\ Réservoirs-IPRA, UMR5150, 64000, PAU, France \\ ${ }^{2}$ TOTAL, CSTJF, F-64018 Pau Cedex, France \\ ${ }^{3}$ CREGU, Université de Lorraine, CNRS, GeoRessources, UMR 7359, BP 70239, F-54506 \\ Vandoeuvre-lès-Nancy, France
}

\begin{abstract}
Several fluid circulation events are recorded in the Aquitaine Basin and the Chaînons Béarnais in the Pyrenean belt of southwestern France. Different fluid types are found in all locations studied. The main difference comes from the thermal peak event (rifting), which was more intense in the Chaînons Béarnais close to the exhumed mantle zone. In situ gas analysis associated of fluid inclusions and isotopic $(\mathrm{C}, \mathrm{O}, \mathrm{H}, \mathrm{S})$ analyses show that similar fluids are generated in both systems, although separated by deep structures, e.g. the North Pyrenean Frontal Thrust (NPFT). The Pyrenean tectonic history leads to the compartmentalization of fluid circulations.
\end{abstract}

\section{Introduction}

The elucidation of fluid circulation is essential to understanding hydrothermal or petroleum systems because they drive the transport of gas, oil, and mineralizing solutions. Often, it is a challenge to identify and integrate a circulation model into its broader geological context. The western Pyrenees and the Aquitaine Basin are well known for their petroleum reservoirs, i.e Lacq oil/gas fields [1]. The origin of fluids here remains under discussion and need to be better constrained. Thus, the aim of this study is to determine the main fluid types and to characterize their sources and migration pathways.

\section{Geological setting}

The area studied is located in the western Pyrenees of France, particularly the Chaînons Béarnais, which comprises the North Pyrenean Zone (NPZ), and the southern Aquitaine Basin (Fig. 1). Sedimentary formations outcropping in the Chaînons Béarnais correspond to the subsurface analogue of the Mesozoic series present in the north of the deep Aquitaine Basin. This basin is composed of Mesozoic and Tertiary sediments in a retro-foreland basin. The sediments are overthrusted by the narrow NPZ along the large-scale structure,

\footnotetext{
* Corresponding author: guillaume.barre@univ-pau.fr
} 
i.e. the North Pyrenean Frontal Thrust (NPFT; Fig.1) [1]. This major structure is characterized by a series of Paleogene folds and thrusts occurring along a south-dipping crustal ramp in the Aquitaine foreland [2].

The Chainnons Béarnais is delimited to the north by the NPFT and to the south by the North Pyrenean Fault (NPF). The Chaînons Béarnais comprises a series of Triassic to early Cretaceous sediments in an E-W fold-thrust structure. This sequence is tilted by southverging thrusts. Early diapirism of Triassic evaporites, followed by Albian to Cenomanian extension (rifting), allowed the formation of the current structure [2, 3]. This setting, correlated to crustal thinning, enabled the exhumation of mantle bodies [4] with maximum temperatures reaching up to $420^{\circ} \mathrm{C}[5]$.

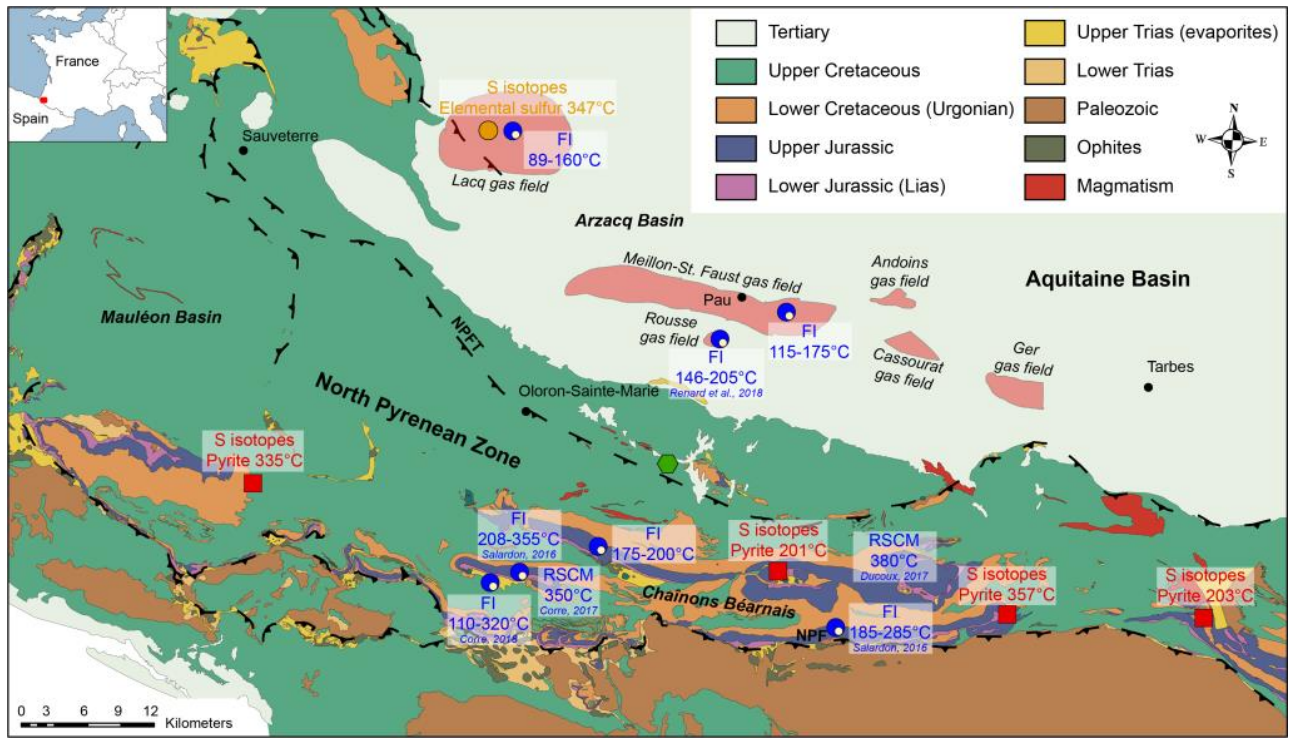

Fig. 1. Geological map of the western North Pyrenean Zone. Temperatures determined by multiple sulfur isotopes, fluid inclusions and Raman spectroscopy on carbonaceous material analysis from this study and literature are also given. NPFT $=$ North Pyrenean Frontal Thrust; NPF = North Pyrenean Fault.

\section{Materials and methods}

We have sampled cores from petroleum wells and representative outcrops from both the Aquitaine Basin and the Chaînons Béarnais. On outcrop, direct gas analyses was performed after borehole drilling (around $40 \mathrm{~cm}$ long and $16 \mathrm{~mm}$ in diameter). The in situ trapped gas concentrations (in \% for $\mathrm{CH}_{4}, \mathrm{CO}_{2}, \mathrm{O}_{2}$ and ppm for $\mathrm{H}_{2} \mathrm{~S}, \mathrm{H}_{2}$ and $\mathrm{CO}$ ) were determined with a GA5000 gas analyser $\left({ }^{\circledR} \mathrm{Geotech}\right)$. Errors were estimated to be $2 \%$ of the full-scale for the respective analyzed gas.

Sulfur-rich minerals (sulfates, sulfides and elemental sulfur) were sampled from the same locations. Reduced sulfur species present in fluid inclusions were released and precipitated as silver sulfide. Multiple sulfur isotope $\left(\delta^{34} S, \Delta^{33} S, \Delta^{36} S\right)$ analyses were performed on all these samples and also on cadmium sulfide powder precipitated from the gas of the Lacq field. Sulfur extraction and fluorination steps (see [6] for detailed procedure) needed for the multiple sulfur isotopes analyses, were conducted at the Institut de Physique du Globe de Paris (IPGP). Fluid inclusions from several calcitic and dolomitic veins and lherzolite associated formations were analyzed by microthermometry and Raman spectroscopy. These techniques permitted the determination of homogenization 
temperatures, salinities and chemical compositions of the different phases present (gaseous, liquid or solid) in specific fluid inclusions.

\section{Results and Discussion}

In-situ gas analyses constrained the timing of the $\mathrm{H}_{2} \mathrm{~S}$ formation by allowing to locate the $\mathrm{H}_{2} \mathrm{~S}$-saturated rocks. Adsorbed $\mathrm{H}_{2} \mathrm{~S}$ was only found in the Middle and Upper Jurassic formations (described as source rocks and reservoirs in the Aquitaine basin [7]), when $\mathrm{H}_{2} \mathrm{~S}$ rich calcite veins are observed exclusively in Late Aptian to Early Albian formations (Urgonian facies) and not in the Upper Cretaceous formations. These evidence constrain the $\mathrm{H}_{2} \mathrm{~S}$ formation by TSR (Thermochemical Sulfate Reduction) to pre- to syn-rift age. This also implies early organic matter maturation which released hydrocarbons subsequently used as reducing agents for TSR.

Multiple sulfur isotopes analysis permits source delineation for the high $\mathrm{H}_{2} \mathrm{~S}$ concentrations. Typical signatures of evaporitic sulfates and sulfides $\left(\delta^{34} \mathrm{~S}\right.$ from +15 to +21 $\%$ and -10 to $+4 \%$ respectively) confirm that the reduced sulfur species are generated by TSR. This is the main process leading to such high sulfide generation in the sedimentary series [8, 9]. Moreover, multiple S-isotope analysis indicates that pyrite formation temperatures range from 201 to $357^{\circ} \mathrm{C}$ (Fig. 1). These pyrites are only observed in Jurassic formations from the Chaînons Béarnais due to the lack of iron in the others series.

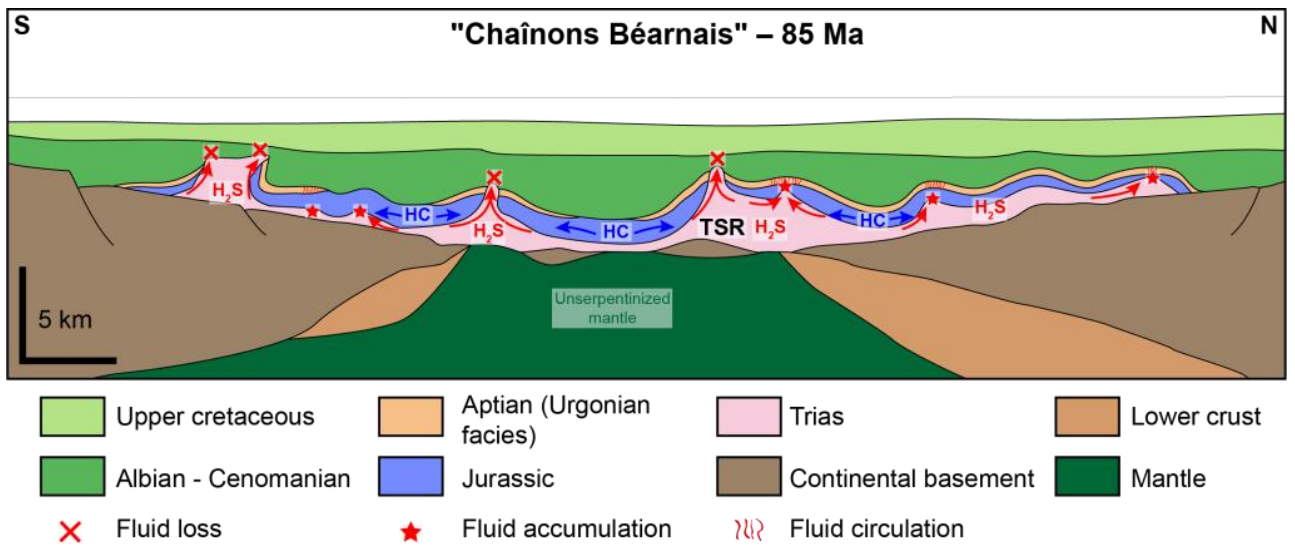

Fig. 2. Restored cross-section of the Chaînons Béarnais at Santonian age (modified from [12]).

Hydrocarbons and $\mathrm{H}_{2} \mathrm{~S}$ generations are showed together with the associated fluid circulation where a part is lost in the pierced diapirs and other is trapped in anticlines allowing overpressure and fracturing events in the upper formation (Urgonian facies).

In addition, fluid inclusions from veins crossing Jurassic formations in the Chainnons Béarnais, document local variabilities in temperatures depending on the type of fluid circulated $[10,11]$. Initially, a hot (up to $350{ }^{\circ} \mathrm{C}$ ) and salty (around $30 \mathrm{wt} \%$ eq. $\mathrm{NaCl}$ ) $\mathrm{H}_{2} \mathrm{~S}$ rich fluid circulated into the upper Jurassic after reacting with hydrocarbons released by the source-rock (mainly Kimmeridgian series). This increases the pressure at the base of the Urgonian facies leading to hydraulic fracturing (Fig. 2) [12]. Then a cooler (lower than 150 ${ }^{\circ} \mathrm{C}$ ) and lower salinity (around $15 \mathrm{wt} \%$ eq. $\mathrm{NaCl}$ ) nitrogen-rich fluid circulated from the Jurassic into lower Cretaceous formations [10]. Multiple S-isotope analysis of the elemental sulfur generated from $\mathrm{H}_{2} \mathrm{~S}$ in the Lacq field exhibit temperatures around $347{ }^{\circ} \mathrm{C}$ for the $\mathrm{H}_{2} \mathrm{~S}$ formation. This implies that TSR occurred deeper in the sub-basin before $\mathrm{H}_{2} \mathrm{~S}$ migration into the Lacq reservoir.

Fluid inclusions from Lacq and Rousse fields also document low-salinity fluids generated by shale compaction, dehydration of clay minerals and late meteoric water 
intrusions in the shallower reservoir. Fluid inclusions from the Aquitaine Basin show similar compositions to the fluids in the "Chaînons Béarnais", but at lower temperatures (less than $170^{\circ} \mathrm{C}$ ). This observation implies similar fluid events in all the areas studied. Only the temperature influence induced by the rifting is markedly different between the two domains; being warmer in the Chaînons Béarnais and cooler in the Aquitaine basin due to its distance from the thinned crust and exhumed mantle during the Albian-Cenomanian extension. In addition, local influence of lherzolite massifs can be observed near these formations, with higher metal contents leading to local pyritisation and precipitation of chromiferous minerals. These interactions probably occurred during emplacement of the mantle bodies into the sedimentary cover, which was contemporaneous to the release of hydrocarbons and $\mathrm{H}_{2} \mathrm{~S}$ production by TSR in the surrounding Triassic and Jurassic formations.

\section{Conclusions}

Considering the Aquitaine Basin and the Chaînons Béarnais architecture together with stable isotopes, fluid inclusions and in-situ gas analyses, a decoupling of hydrothermal circulations in these two main systems has been documented. The Chaînons Béarnais reached much higher temperatures than in Arzacq and Mauléon basins. However, both systems present very similar fluid compositions. Coupling of these different techniques show that fluid circulations are compartmentalized into sub-basin, all linked to the Pyrenean geodynamic history.

This work has been funded by Total. The authors wish to thank Pierre Cartigny from the "Institut de Physique du Globe de Paris" (IPGP) to open his laboratory for the multiple sulfur isotope analyses.

\section{References}

1. J.J. Biteau, A. Le Marrec, M. Le Vot, J.M. Masset, Pet. Geosci., 12, 247-273 (2006)

2. A. Teixell, P. Labaume, Y. Lagabrielle, C.R. Geosci., 348, 257-267 (2016)

3. S. Jammes, G. Manatschal, L. Lavier, E. Masini, Tectonics, 28, 24 (2009)

4. Y. Lagabrielle, P. Labaume, M. de Saint Blanquat, Tectonics, 29, 26 (2010)

5. C. Clerc, A. Lahfid, P. Monié, Y. Lagabrielle, C. Chopin, M. Poujol, P. Boulvais, J.-C. Ringenbach, E. Masini, M. de St Blanquat, Solid Earth Discuss., 7, 797-857 (2015)

6. Y. Kitayama, E. Thomassot, A. Galy, A. Golovin, A. Korsakov, E. d'Eyrames, N. Assayag, N. Bouden, D. Ionov, Chem. Geol., 455, 315-330 (2017)

7. J. Connan, G. Lacrampe-Couloume, Appl. Petrol., 3, 464-488 (1993)

8. W.L. Orr, Am. Assoc. Pet. Geol. Bull., 58, 2295-2318 (1974)

9. C. Cai, R.H. Worden, S.H. Bottrell, L. Wang, C. Yang, Chem. Geol., 202, 39-57 (2003)

10. R. Salardon, C. Carpentier, N. Bellahsen, J. Pironon, C. France-Lanord Mar. Pet. Geol., 80, 563-586 (2017)

11. B. Corre, P. Boulvais, M. C. Boiron, Y. Lagabrielle, L. Marasi, C. Clerc Mineral. Petrol., 112, 1-24 (2018)

12. S. Renard, J. Pironon, J. Sterpenich, C. Carpentier, M. Lescanne, E. C. Gaucher, Chem. Geol., in press (2018)

13. A. Teixell, P. Labaume, P. Ayarza, N. Espurt, M. de Saint Blanquat, Y. Lagabrielle, Tectonophysics, 724-725, 146-170 (2018) 